\title{
Trends of Mobile Learning in Mathematics
}

\author{
H Patmawati ${ }^{1}$, R Hermanto ${ }^{2}$, I Muzdalipah ${ }^{3}$ \\ $\left\{{ }^{1}\right.$ hettypatmawati@unsil.ac.id, ${ }^{2}$ redihermanto@unsil.ac.id, $\left.{ }^{3 i p a h m u z d a l i p a h @ u n s i l . a c . i d ~}\right\}$ \\ ${ }^{1,2,3}$ Universitas Siliwangi Tasikmalaya, Indonesia
}

\begin{abstract}
This article presents the learning process that uses mobile learning, math mobile, mobile applications in mathematics learning. In this era of technology and sophisticated, mobile technology service devices are very supportive in the learning process, both in local and global contexts, mobile learning is a new paradigm in learning using mobile technology and wireless networks. The method used is discourse analysis. The results of the analysis of various articles about the use of mobile learning and learning activities in learning mathematics from various countries, namely the existence of mobile learning technology is the same as learning grip technology that can be accessed anywhere, by anyone together with wireless networks and cell phone networks so that can facilitate, support, improve and expand the reach of students in learning mathematics. Various benefits of mobile learning mathematics are: exploring mathematics freely, learning mathematics through teamwork, learning mathematics in social and human environments, learning mathematics in authentic real-life situations, visualizing mathematics and investigating dynamically, learning mathematics smoothly and efficiently using sophisticated technology so that it can support learning activities.
\end{abstract}

Keyword: Mobile Learning, Learning Activities, Learning Mathematics

\section{INTRODUCTION}

Mathematics is known as the science of numbers, abstract, deductive, logical, and emphasizes more on thinking and reasoning. It is very challenging for students both in primary and secondary schools throughout the world. Some countries, especially in developing countries, have adopted different methods and approaches to try to overcome challenges. In the field of computer science and information communication technology, mathematics plays an important role. At present technological developments, there is a great interest in utilizing the considerable appeal and availability of mobile devices for education[1]. As a result, various mobile technology education applications (mobile learning or m-learning) are on the trend[2].

With Mobile learning, an environment is introduced in learning new things because of the advent of mobile technology and wireless networks[3]. Various cellular communication mechanisms support mobile learning, such as voice communication, access to learning portals on the internet, and learning via SMS. Mobile learning as an interactive media by combining the convergence of audio, web, and mobile technology in one complete package. Mobile devices like smartphones and 
media players are getting stronger, more convenient, and everywhere. This device has changed the way people communicate, search for information, and work with data from various forms [4].

Globalization era can easily absorb from mobile services, seen from the increasing number of users of various ages can take advantage of mobile learning services, thus posing challenges for designers. The era of mobile devices and services has opened up a whole new way of learning to make information possible accessible to everyone and wherever they are. Mobile devices in education, one of the informal digital practices as a high potential for changing mathematics in different classes[5]. Mobile devices are very flexible, computing devices, but there are many uses. Various mobile features are used to build mathematical knowledge.

\section{RESEARCH METHOD}

The method used is discourse analysis. Discourse analysis is a way or method to study the discourse contained in ideas and messages contained in an article, both textually and contextually[6]. Through discourse analysis of various articles on mobile learning can reveal various facts about the use of mobile learning in various developing countries, so that it can be assessed whether in Indonesia can also be used in learning, especially mathematics learning. A researcher can conclude the text, and words explained when the general definition is not enough to understand the message of the author[7].

\section{RESULT AND DISCUSSION}

Students born in the current era who are equipped with various digital technologies bring them different changes in learning. They have access to several sources of information, multitasking and socially connected to friends, through mobile devices.

Mobile devices are cheaper than personal computers and are widely used because of the more affordable prices such as mobile phones/smartphones as one of the necessities that must be had for everyone. The latest developments in mobile and wireless technology have new M-Learning or mobile learning modes. Many students prefer mobile learning because it can accommodate a variety of features and service sections that offer a highly interactive learning experience. Mobile learning can complement e-learning by creating additional channels of access for users from mobile devices such as smartphones, PDAs, MP3s, MP4 Players, Laptops / Netbooks, Ipads, and Tablets[8].

In this paper, the author explains the trend of mobile learning in learning mathematics that is being developed by several countries today. The author analyzes from several articles that discuss mobile learning in learning mathematics in developed and developing countries.

\section{a. Malaysia}

The mobile learning project that is implemented focuses on learning mathematics in elementary schools in Malaysia. His prospects of implementing mobile learning include significant and challenges of m-learning and students' perceptions of the use of mobile learning in mathematics. Includes an online mobile quiz, tracking student learning progress. M-learning is different from elearning.

E-learning is intended to strengthen and harmonize overall learning strategies, while mlearning offers another way to deliver learning content into daily life by developing learning materials in the consumption of byte formats that are transmitted over wireless networks. 
Implementing mobile learning for elementary schools in Malaysia by using open source might prove the potential of a new mobile learning environment. The model developed, MobileMath, focuses on learning mathematics which allows students to conduct lessons, quizzes, exams, and performance tracking with electronic charts[3].

Learning activities with mobile learning are no longer controlled by the teachers entirely in the classroom but also makes it possible for students to learn anything they want at any time and in any place even though outside the school area.

\section{b. Israel}

Reports on research results in Arab secondary schools in Israel in the field of teaching mathematics using mobile phones. There were 32 teachers and eighth-grade students to carry out outdoor activities in real life, analyzing students' perceptions about learning mathematics using smartphones. The results found that the use of mobile phones in mathematics learning is the main characteristic felt by students which can influence their learning. In addition, students can experience various qualities of Mathematics learning that are activated by using a cellphone/smartphone: (1) can explore mathematics widely (2) learning together with groups (3) learning Mathematics in social and human environments (4) learning in life everyday (5) gives a broad picture of mathematics (6 doing mathematics learning activities using sophisticated technology (7) learning easily, effectively and efficiently). Overall, students were positively impressed by the potential and capabilities of the cellular phone used in the Mathematics learning process. It shows that mathematics education can benefit in the form of utilizing these new technological tools[9].

Student activities in online learning, so the distance learning process and online learning have a significant relative advantage for independent learning.

\section{c. Namibia}

A case study in a secondary school in Namibia. Mathematics becomes one of the most important lessons that must be taught at every level of education. The results of previous research presented by Agustine et al., entitled Mobilemath innovative solutions to the problem of student mathematics learning outcomes still lack in the Caribbean region, explaining that there is an increase in mathematics results after using the system mobile learning and smartphones in mathematics.

In secondary schools, the mathematics learning system is implemented using Interactive Mobile, but not all schools want to utilize the technology of mobile learning, due to the lack of use of mobile learning to improve the teaching and learning process of mathematics[10]. One of the advantages of mobile learning technology is that affordable mobile applications are expected to help students in learning. Go-Math was made to support learning activities and discussion of mathematics between families.

Learning activities with the use of Go-Math mobile learning can be used anywhere and anytime. There are only a few obstacles faced by both teachers and students not wanting to use their smartphones for learning activities. They do not believe that the smartphone can help in learning. They mostly use smartphone features in general. 


\section{d. Iran}

The results of the study [11], concluded that the effect of the use of technology about games in elementary school students in learning mathematics could change attitudes and creativity in learning mathematics. The sophisticated technology in mobile can open a window for the next generation and make the teaching and learning process happen when and where students are. Supported technology can help students to construct abstract concepts that are difficult to understand but can also facilitate whatever is in students' minds through several graphical theorems and multidimensional studies. The combination of new generation and digital mobile technologies enhanced cognitive and social skills in current learning concepts[12].

Mobile learning is a device for utilizing a cell phone along with a cell phone network, which can facilitate, enhance, and expand the range of learning and teaching processes. With the existence of mobile technology, we can attract information and provide learning processes at any time and place anywhere. Mobile devices are cheaper than personal computers and are used by many people because almost everyone has a cell phone [13]. The use of advanced technology in the learning and assessment process through mobile learning tests enables students to develop when used according to their needs or experience.

Activities in the teaching and learning process outside the classroom; learning anywhere and anytime is not limited by time. Cellphone lifters such as cellphones/smartphones, laptops, iPad, and tablets in which there are learning features or software so that students can learn mathematics effectively.

\section{e. South Africa}

Many researchers in the field of education have researched how to support the activities of the learning process through mobile technology in the local and global environment, focusing on how to develop and evaluate mobile learning services from the results of learning mathematics. With the use of mobile devices and services, students can access new ways of learning mathematics that obtain information for everyone, every time and everywhere. The project was carried out in secondary schools in rural and urban areas in southern Africa. With the main problem, what culture can be considered when designing mobile technology in learning and learning mathematics in South Africa[14].

Learning with mobile devices is a global goal and phenomenon educational principles for all and the development of mobile learning technology concepts. Students develop new skills and literacy that are activated by mobile devices such as SMS texting, moblogging, and mobile video creation[15]. Mobile learning is a global phenomenon that must be analyzed critically. Several studies have been made on how to design, develop, and evaluate mobile learning. However, only a few foci on the development of mobile learning, systems, and local cultural contexts, where mobile learning takes place [16].

Student learning activities in South Africa can occur at anytime and anywhere using a mobile device, can contain additional information or exercises, which are designed according to a more specific curriculum. 


\section{CONCLUSIONS}

Mobile Learning is a mobile device that is a new trend in learning mathematics with the emergence of the use of mobile and wireless technology among students. Mobile learning can be as successful as it is today and in the future, because at this time PDAs and Tablets are more popular among many people. Mobile learning is different from e-learning in terms of mobility and interaction between students and teachers. Mobile devices enable students to explore and experiment with concepts they have learned while the teacher can control the level of difficulty of students. The contents of mobile learning can be more interesting for students because of new concepts and new ways to learn.

\section{REFERENCES}

[1] T. White, \& L. Martin. 2014. Mathematics and Mobile Learning. Journal Tech Trends. January/February. Vol. 58. Issue. 1

[2] M. Kearney, D. Maher. 2013. Mobile Learning in Maths Teacher Education: Using Ipads to Support Pre-Service Teachers Profesional Development. Australian Educational Computing. Vol. 27 no. 3. P 76-84.

[3] M. Saipunidzam, M. Ibrahim and S. Taib. 2010. M-Learning: A New Paradigm of Learning Mathematics in Malaysia. IJCSIT volume 2, Nomor 4. Agustus 2010

[4] H. Crompton, D. Burke. 2018. The Use of Mobile Learning in Higher Education: A Systematic Review. Journal Computers and Education. Vol 123. Issue April. P 53-64.

[5] S. Batista, P. Behar, L. Passerino. 2010. Mobile Learning Environments and Applications MLearning in Mathematics: Mapping requirements. Conference ICL 2010. September 15-17, Hasselt, Belgium.

[6] J. Foster, R. Grenier, E. Taylor. 2019. Discourse Analysis: A novel Analytical Technique for Qualitative Nutrition Research. J Nutr Edue Behav. 2019;000:1-8.

[7] M. Jhonson, N. Mercer. 2018. Using Sosiocultural Discouse Analysis to Analyse professional discourse. 2210-6561. Elsivier Ltd.

[8] A. Drigas \& M. Pappas. 2015. A Review of Mobile Learning Applications for Mathematics. IJIM. July

[9] N. Baya, N \& W. Daher. Student's Perception of Mathematics Learning Using Mobile Photo. ICML 2009. April 21-24 Amman, Jordans

[10] A. Kachepa \& N. Jere. Implementation of Mobile Games for Mathematics Learning: a case of Namibian Schools. IJSKCIT. Sept 2014. Vol 4 nomor 5.

[11] Y. Shin, E. Mills, et al. 2007. Setting the New Standard with Mobile Computing in Online Learning, The International Review of Reseach in Open and Distance Learning. vol 8, no 2

[12] N. Shin, L. Sutherland, C. Norris, C. et al. 2012. Effects of Game Technology on Elementary Student Learning in Mathematics. Britsh Journal of Educational Technology. Vol 43, issue 4. P 540-560

[13] Z. Taleb, A. Ahmadi \& M. Musavi. 2015. The effect of m-learning on mathematics learning. ICPEESY. Journal Elsevier. Procedia Social and Behavioral Sciences Vol 171. P 83-89 
[14] T. Walsh, T. Vaino \& J. Vasaluoma. 2014. Cross-Cultural Design of Mobile Mathematics Learning Service, four South African School. ICEMAL 2014. ISBN: 978-989-8704-02-3. P 7584

[15] M. Sharples, J. Taylor, \& G. Vavoula. 2010. A theory of learning for the mobile age: learning through conversation and exploration across contexts. In: Bachmair, Ben ed. Medienbildung in Neuen Kulturräumen: die deutschprachige und britische Diskussion. Wiesbaden: VS Verlag für Sozialwissenschaften, pp. 87-99.

[16] R. Rahim, K. Saddhono, and D. Sulaksono. Unified modeling language as a design of interactive ebook application for android. Journal of Advanced Research in Dynamical and Control Systems. vol. issue. 5 pp. 634-637, 2019 